\title{
MULTICULTURAL EDUCATION AS SEEN IN FORREST CARTER'S THE EDUCATION OF LITTLE TREE
}

\author{
Ignatius Indra Kristianto \\ Universitas Atma Jaya Yogyakarta \\ ignatius.indrakris@yahoo.com \\ DOI: https://doi.org/10.24071/ijhs.2017.010104 \\ received 14 April 2016; revised 28 February 2017; accepted 11 July 2017
}

\begin{abstract}
This paper's primary purpose is to examine the concept and the impact of multicultural education that is seen in The Education of Little Tree. This paper employs American Studies perspective and Historicism theory in order to obtain the purpose of the study. Using American Studies perspective, this research views Native Americans as indigenous people of America. Using Historicism theory, this research is able to uncover the concept and the impact of multicultural education in the novel by viewing the socio-historical context that is referred by the novel and the socio-historical context when the novel was written and then published. Based on the analysis, it can be concluded that the concept of multicultural education that is seen in the The Education of Little Tree is similar to the concept that is promoted by the experts of multicultural education. The education that is given by the grandparents promotes cultural pride, knowledge of historical information of a culture, and respect towards other cultures. Furthermore, there are several positive impacts of multicultural education that is seen in The Education of Little Tree, they are: first, children possess cultural pride; second, children possess the historical knowledge of their own culture; third, children possess the cultural knowledge of other cultures in their society; and fourth, children respect other cultures in their society.
\end{abstract}

Keywords: concept, multiculturalism, impact, Native American, education

\section{Introduction}

Education is an interesting topic to be explored since education is very important for everyone. Education can serve as a means to elevate a person's knowledge and status in a society. On the other hand, education can serve as a means to control and rule minority groups in a society. One of the examples was education that was given to Native Americans. Native Americans were forced to assimilate into America, since Native Americans were considered as uncivilized people. One of the ways to assimilate Native Americans was to educate Native Americans children using education that is based on whites' educational system.

Fortunately, the civil rights movement in the 1960s changed the perspective of many Americans. Americans began to insert multiculturalism into their educational system. Thus, the concept of multicultural education started to emerge 
in America. Based on those backgrounds, this paper investigates about the concept of multicultural education through the education that is given to Native Americans. In order to achieve that goal, this paper primary purpose is to examine the concept and the impact of multicultural education that is seen in The Education of Little Tree.

\section{Theory}

This research applies American studies perspective as the foundation for explaining the concept of multicultural education and its impact as seen in The Education of Little Tree. In his work Paradigm Drama, Tremain McDowell (1948) (as cited in Merideth, 1968) explains that, American Studies is a "synthesis of knowledge" which applies interdisciplinary approach as a holistic study of American culture. It is challenging to conduct a study on the concept and the impact of multicultural education as seen in The Education of Little Tree since Lucy Maddox (1999) stated that American Studies as an academic enterprise devoted to the interdisciplinary study of American history and culture. The Civil Rights movement in America in the 1960s and 1970s changed American Studies' theory and method. American Studies scholars explored wider boundaries such as black studies, gender studies, ethnic studies, etc. Based on those statements, this paper conducts a research about education which was given to Native Americans children.

To analyze the concept of multicultural education and the impact of multicultural education as seen in The Education of Little Tree this paper employs Historicism theory in its analysis. Raman Selden (2005) argued that Historicism was the offspring of Hegelian idealism and several major 'historicist' studied literature in the context of social, political and cultural history. According to Palmer (1987), Historicism is usually reserved for that approach to literature which sets it in the context of ideas, conventions and attitudes of the period in which it was written. By using Historicism theory this paper is able to uncover the concept and the impact of multicultural education in the novel by viewing the socio-historical context that is referred by the novel and the socio-historical context when the novel was written and then published.

The descriptive qualitative method is applied in this paper. Creswell (2003) stated that qualitative method was described as an approach used to gather data systematically, but the data were purely descriptive, and therefore not numerical. The paper also applies library research in order to obtain better understanding of the problem and in order to obtain data for the research. The complete study of this paper contains of data collection and data analysis. In data collection, the researcher applies library research in order to obtain better understanding of the problem and to obtain data for the paper. The data is divided into two categories: primary data and secondary data. Primary data used in this paper is a novel entitled The Education of Little Tree by Forrest Carter. The secondary data are any data gathered from books, journals, research papers, e-books and e-journals which support the analysis of the research.

\section{Multiculturalism and Multicultural Education}

The idea of a multicultural society has become an official policy in many Western cultures and represents a liberal democratic attempt to promote ethnic or 
racial equality. Baker (2004) stated that as a policy approach it has been influential in the education and cultural spheres where it has underpinned attempts to introduce people to a range of different beliefs, values, customs and cultural practices. For example, the teaching of multi-faith religious education and the performance of rituals became facets of educational policy. Furthermore, according to Feinberg (1996), there are three main goals of multiculturalism in education, namely: 1) cultural pride should be encouraged, 2) cultural respect should be fostered, and (3) cultural information should inform children about the range of historical experiences that have affected those who are or have been considered culturally different.

From the previous concept of multiculturalism, educational practitioners inserted multiculturalism into educational system. Multicultural education has been used by countries all over the world in referring to educational efforts that have attempted to inculcate more positive values about human pluralism and improve the learning potential for all students. According to Ellen Swartz (1992), multicultural education is an education that uses methodologies and instructional materials which promote equity of information and high standards of academic scholarship in an environment that respects the potential of each student. Furthermore, according to James A. Banks (1997), multicultural education as an idea holds that all students - regardless of their gender, social class, ethnic, racial, or cultural characteristics - should have an equal opportunity to learn.

\section{The Socio-Historical Context of the Novel}

In the early $19^{\text {th }}$ century, education for Native Americans was mainly proposed by missionaries and ex-generals of American army. Some Native Americans children were put under white educational system in order to assimilate them. Native Americans children as young as five years old were sent to the boarding schools. According to Engan-Barker (2004), the shock, fear, and loneliness which these children faced upon being uprooted from everything familiar and known can only be imagined.

As the new century began, the continued inability of boarding schools and English-only education to transform Native Americans into white people led to disillusionment and lowered expectations for Native Americans education. EnganBarker (2004) stated that increasingly, Native Americans were viewed in the same light as blacks at that time: as a permanent underclass for whom an inferior, nonacademic, vocational education was appropriate and adequate.

The life of Native Americans changed during the 1970's, under Presidents Richard Nixon, Gerald Ford, and Jimmy Carter. In May, 1977, the congressional American Indian Policy Review Commission, which included five Native Americans members for the first time, made more than two hundred recommendations, most of which aimed at confirming all tribes' power to enact laws within the confines of their own reservations. The condition also changed in the educational system for Native Americans. The Indian Education Act in 1972 provided for special programs benefiting Native Americans children in reservation schools as well as those attending urban public schools. It was amended in 1975 to require that Native Americans parents be involved in the planning of these programs. 
In 1960s the USA experienced Civil Rights Movement. Civil Rights Movement changed cultural point of view in America. Oppressed ethnic groups in America started to fight for their civil rights. The need of education was the trigger of Civil Rights Movement. Civil Rights Movement also brought impact to Native Americans. A significant but controversial piece of legislation designed to guarantee the rights of individual Native Americans came about in special Native Americans titles of the Civil Rights Act signed into law on April 11, 1968. According to Barret (2003), federal recognition or regulation of tribes does not make them part of the United States government or guarantee constitutional protection for tribal members. The existence of tribal governments and tribal courts had raised the issue of protection of the individual rights of Native Americans living in a tribal context.

\section{Theory Application}

\section{The Concept of Multicultural Education in the Novel}

In order that Little Tree may be able to live successfully and harmoniously in a culturally diverse society, he needs to comprehend firstly about the culture of his own tribe, the Cherokee. It is a custom for Native Americans that many hours are spent with their elders, especially grandparents. They do that in order to learn tribal history and myths. Children are the key to the future, and elders seek to instil in them the tribe's ancient traditions. Little Tree needs to understand the reasons behind his grandparents' choice of a way of life. He also needs to understand the way of life of his people, the Cherokee. The knowledge of Cherokee's way of life is very important for Little Tree so that he is aware where he is and where he belongs in the society. That way, Little Tree may not be carried away by the dominant culture of his society.

The first thing to be introduced to Little Tree about Cherokee's culture is about the traditional religion of Cherokee. Cherokee believes in the existence of spirits. The strongest spirit for Cherokee is the earth mother. The second thing to be introduced to Little Tree about Cherokee's culture is about Cherokee's way in fulfilling their daily needs. Since Cherokee depends heavily on the nature to fulfil their daily needs, it is very important to take care of the nature. Cherokee will only take what they need from the nature. The grandmother added the knowledge about Cherokees' way in fulfilling their daily needs by giving information about plants. The grandfather added the knowledge about Cherokees' way in fulfilling their daily needs by giving information about Cherokees' system of planting. The Cherokees' system of planting is different from the white's system of planting. The third thing to be introduced to Little Tree about Cherokee's culture is about Cherokee's way to handle things, such as facing a situation or solving a problem. Little Tree learns that in order to solve any problem in his life, he must keep his cool and use senses all the time. That way, he may be able to find the best solution for his problems. The grandmother adds the knowledge of Cherokee's way to handle things by giving the knowledge of body living mind and spirit mind. By using spirit mind, Little Tree may be able to understand more about the nature and other people that he encounters in life. Furthermore, by using spirit mind, Little Tree may be able to see the true nature of people who he meets. He can also read 
the signs from the nature because sometimes nature gives out signs in order to give hints that something is going to happen.

In the early twentieth century, American government showed little interest in retaining Native Americans' culture. However, in 1928 there was an investigation conducted by Lewis Meriam, a student of Native Americans culture. She criticized American policy that showed no intention in preserving Native Americans' culture. The report of investigation advocated spending more money for economic assistance and suggested that the aid go directly to local tribal councils. The councils, rather than Bureau of Indian Affairs officials, should decide how to spend the funds. According to Tischauser (2003), Meriam called for a policy of cultural pluralism: Native Americans should be allowed to live by their old customs and values if they chose. It would lead to milestone legislation in 1934, the Indian Reorganization Act.

The second knowledge that Little Tree needs to comprehend is the knowledge of the history of Cherokee. It is very essential that Little Tree comprehends the history of his own tribe. The Cherokees lost their land although they had established the Cherokee Nation. According to Pritzker (1998), the Cherokees Nations was founded in 1827 with "western" democratic institution and a written constitution (which specifically disenfranchised African Americans and women). After the finding of gold in Cherokee's land, most of Cherokee were forced to move to the west of Mississippi River. The government passed the 1830 Indian Removal Act. They were forced to live in reservation. Some Cherokee who could escape from the forced removal to the west stayed to live in the mountains of North Carolina.

The history of Cherokee that is told by the grandparents to Little Tree is the Trail of Tears. It reveals to Little Tree that despite the Cherokees were in a sorrowful condition, they held their pride as Cherokee very high. It is the reason behind the preservation of Cherokee's culture and way of life. They do not want to lose their identity as Cherokee, so they maintain their way of life and culture despite being oppressed and dominated by white's culture. The government tries to civilize Native Americans in order to assimilate them into white's society without considering the existing Native Americans' culture and way of life. American government wants to educate Native Americans children using white's educational system so that Native Americans can merge into white's society.

The third knowledge that Little Tree needs to comprehend is the knowledge of other cultures in the society. This knowledge is related to the word kin. For Cherokee, understanding is more important than love. Little Tree must understand the reasons behind an act by a person before he falls into negative prejudice of that person. The same also applies for other culture. Little Tree has to understand other culture so that he knows the reason behind the existence of cultural differences.

The first knowledge of other cultures in Little Tree's society is the knowledge of other religion. Little Tree becomes aware that each religion possesses its own ritual. Cherokee embrace Mon-o-lah by enjoying the beauty of nature and at the same time preserving the nature. Christians accepted God by being baptized using water. However, different denominations have different ways in baptizing using water. And sometimes they fight about it. Little Tree is 
amazed at the fact that those Christians worry about water that much. He thinks that water is abundant in the nature and everyone can use it as they want. It means that nature is a gift from earth mother and no one can claim it as their possession. It is different from the whites who think that possession of natural resources is very important.

The second knowledge of other cultures in Little Tree's society is the existence of white's culture. In the early twentieth century, the dominant culture was the white's culture. The grandmother shares this knowledge to Little Tree through books. Grandfather explains to Little Tree that the whites have different method in agriculture. Since, the whites are ignorant to the nature. The whites will utilize the nature as they please and they will take from the nature as many as they can. It is a comparison between modern agriculture and traditional agriculture. In the early twentieth century, modernization in agriculture meant that farmers were able to produce more. Farm began to grow larger. Landowner possesses hectares of land. New investors in modern agriculture approach the politicians in order to grab more land from Native Americans. Little Tree becomes aware that the possession of land is very important for the whites.

The third knowledge of other cultures in Little Tree's society is the existence of sharecroppers. Sharecroppers are the opposite of wealthy landowners. Sharecroppers are poor farmers that possess no land. In order to earn a living, they have to work for a landowner. Similar to Native Americans, sharecroppers also received prejudice from the society. They are considered as lazy and irresponsible. Little Tree comprehends that prejudice can happens to anyone in the society. Even white Americans may receive prejudice from the society.

The grandparents share the knowledge of the culture of Cherokee, the history of Cherokee, and the knowledge of other culture in their society because this knowledge is something good that need to be shared. Cherokee believes that if a person possesses something good, it is better to share it with anyone. Multicultural education as a concept is something good that must be shared to everyone. So that respect and embrace of cultural difference will be accepted by a lot of people.

\section{The Impact of Multicultural Education in the Novel}

The first impact that can be seen from the novel is that Little Tree possesses the cultural pride of Cherokee's culture. Following the teaching from his grandfather, Little Tree will follow "The Way" of the Cherokee. Little Tree takes only what he needs from the nature. If natural resources are not protected, the younger generations will be able to utilize them. Furthermore, Little Tree experiences the educational system of the whites when he is forced to live in a Christian orphanage by the law. The grandmother already introduces Little Tree to whites' culture through books that she reads every Sunday night. However, it does not alter Little Tree's identity of being a Cherokee. It can be seen when Little Tree is in the Christian's orphanage. When Little Tree is asked by Wilburn about what will he do when he grows up, Little Tree answered that he wants to be a Native American. Since he has cultural pride of being a Cherokee, he wants to merge with the society without losing his identity as a Cherokee.

The second impact that can be seen from the novel is that Little Tree possesses the historical knowledge of his tribe, Cherokee. Little Tree aware that 
the possession of land is an important matter for the whites. Little Tree knows that Cherokee used to live in a very vast fertile land. Unfortunately, the government took the land from Native Americans by force. Little Tree comprehends that Cherokee was forced to move from their land because the whites found gold on the land. Little Tree comprehends that in Cherokee's point of view a person or a tribe cannot survive without land. However, Cherokee does not have the concept of land possession. Land is a gift from earth mother that needs to be preserved for the survival of Cherokee. Little Tree also becomes aware the historical background behind his grandfather's trade of whiskey making.

The third impact that can be seen from the novel is that Little Tree possesses the knowledge of other culture in his society. Little Tree becomes aware that the dominant culture in his society is the whites' culture. The domination of whites' culture to the culture of Native Americans can be seen through the infiltration of Christianity in the American government policies towards Native Americans. However, the policies are altered in 1978. According to Cannon (2003), on the heels of this symbol of intended reform, the U.S. Congress passed the 1978 American Indian Religious Freedom Act, which guaranteed freedom for tribes to practice their own traditional religions. This act ended the mixed legacy of several centuries of insistence that missionary conversion and education following Christian principles were vital aspects of Native Americans-white relations in the United States.

Little Tree becomes aware that the cultural difference between Native Americans and whites can bring misunderstanding and prejudice. The knowledge of other culture makes Little Tree grow up as a boy who is not naïve or who doesn't think that all people are nice. His grandparents already teach him the existence of bad person in other culture. Little Tree is encouraged to use his senses in order to know whether a person is nice or bad. He also learns to be more careful in dealing with another person.

Little Tree becomes aware that the society where he lives in is in trouble. White's culture is all about earning a lot of money. Unfortunately, when the system is damaged, the whites cannot handle the condition well. Pine Billy says that the world was coming to an end. He said there are rumours of wars, and famine had set on the land. Banks are mostly closed and those that are not closed are being robbed all the time. Pine Billy says there is no money to be had hardly at all. He says that folks are still jumping out of windows in the big cities whenever the notion took them. Little Tree understands that the event is the Great Depression. Unlike the whites who get influenced heavily by the Great Depression, Native Americans do not feel the impact of the Great Depression. Especially for those who still depends on the nature in providing their daily needs.

The fourth impact that can be seen from the novel is that Little Tree is respecting other culture in his society. Little Tree possesses understanding of other people in his society through the grandparents' teaching and his own experience. He comprehends that he needs to possess good understanding so that he will not fall into prejudice for other people in the society. It is appropriate with the lesson from the grandfather. Understanding is important for Cherokee. Thus, Little Tree needs to understand other people in the society. Little Tree is committed in trying to understand other people in the society. He respects the 
sharecropper family who has to move from one land to another. He respects $\mathrm{Mr}$. Jenkins who is fair in doing whiskey trading with the grandfather. Furthermore, Little Tree respects the whites' orientation for money. One of them is the small family's acquaintances, Mr. Wine. He is a Jew who lives in the settlement but earns his living by fixing clocks. Little Tree respects the fact that that Mr. Wine is a thrifty person. Since, Little Tree has respect towards Mr. Wine; Mr. Wine gives back the respect by teaching Little Tree about figures and reading the time.

Little Tree possesses the experience of having education using the whites' system. Little Tree is forced to go into a Christian's orphanage by the government. Little Tree does not like to live in the dormitory because it does not appreciate cultural differences. It only promotes how to be a good citizen and assimilate into white's society. The Reverend who leads the orphanage does not acknowledge Little Tree's parents' marriage. That is why, Little Tree is considered as a bastard who cannot be saved according Christian's point of view. Little Tree wants to live in a society where the people are respecting each other without having any prejudice. Furthermore, by possessing the knowledge of other culture's religion, Little Tree develops a certain point of view towards those religions. When facing white's religion, he is in the position of onlooker. That is why when Little Tree is forced to go into Christian's orphanage, he does not complain when he is prohibited from attending the mass.

If there is understanding in the society, everyone may be able to work together without any prejudice. Little Tree gets this lessons from his grandfather. The grandfather has an experience of witnessing this kind of unity when he was a child. Two whites were working together with a black man in order to plough the land. It shows that unity between quarrelling parties can be achieved. Little Tree is amazed by the story. He realizes that unity in the society may be achieved through understanding which resulted respect for other culture in the society.

The American government showed respect towards Native Americans when they enacted the Indian Self Determination and Education Assistance Act of 1975. The act marked a radical change in federal policy - the assimilationist philosophy of the federal government was replaced by policies favoring tribalism and Native Americans sovereignty. According to Barret (2003), the act clearly endorsed Native Americans decision making, and the preamble declared that the United States recognized its obligation "to respond to the strong expression of the Indian people for self-determination by assuring maximum participation in the direction of educational as well as other federal services to Indian communities so as to render such services more responsive to the needs and desires of those communities."

\section{Conclusion}

The concept of multicultural education in The Education of Little Tree can be seen from the education that is given by the grandparents to Little Tree. The concept of multicultural education that is seen in the grandparent's education is similar to the concept that is promoted by the experts of multicultural education. The education from the grandparents promotes the encouragement of cultural pride in children. The education from the grandparents also promotes the introduction of historical events that have affected those who are or have been 
considered as culturally different. In that manner, children may be able to understand better those who are or have been considered as culturally different. Furthermore, the education by the grandparents also promoted that children's respect towards other cultures should be fostered.

The concept of multicultural education that is seen in The Education of Little Tree also rejects the assimilation purpose of white's educational system. Children shall be able to merge into the society without losing their cultural identity. Thus, the concept of multicultural education encourages the maintenance of native rituals and cultures in education. Teachers should encourage children to perform their rituals and cultures, such as traditional dances and songs. Furthermore, education in a democratic society shall require teachers to respect the rights of students to be culturally different.

There are several positive impacts of multicultural education that can be seen from The Education of Little Tree. The first impact is that children possess cultural pride. The second and third impacts of multicultural education are that children possess the historical knowledge of their own culture and knowledge of other cultures in the society. The fourth impact of multicultural education is that children are respecting other cultures.

It is fascinating that The Education of Little Tree captures the spirit of multiculturalism in its story. The Education of Little Tree considers that multicultural education as a concept is something good that must be shared to everyone. With that, respect and acceptance of cultural differences are practiced by all the people.

\section{References}

Banks, J. A. (1997). Multicultural education: Theory and practice (6 $6^{\text {th }}$ ed.). Boston: Allyn and Bacon.

Baker, C. (2004). The SAGE dictionary of cultural studies. London: SAGE Publications Ltd.

Barrett, C. A. (2003). Indian civil rights act. In Carole A. Barrett (Ed.), American Indian history (pp. 193-196). Pasadena, CA: Salem Press Inc.

Cannon, Byron D. (2003). Indian-white relations: U.S., 1934-2002. In Carole A. Barrett (Ed.), American Indian history (pp. 292-300). Pasadena, CA: Salem Press Inc.

Creswell, J. W. (2003). Research design: Qualitative, quantitative and mixed methods approaches ( $2^{\text {nd }}$ ed.). California: Sage Publications, Inc.

Engan-Barker, D. (2004). Education: Post-contact. In Carole A. Barrett and Harvey J. Markovitz (Eds.), American Indian culture (pp. 245-254). Pasadena, CA: Salem Press Inc.

Feinberg, W. (1996). The goals of multicultural education: A critical reevaluation. New York: Philosophy of Education.

Maddox, L. (1999). Locating American studies: The evolution of a discipline. Baltimore and London: The John Hopkins University Press.

Merideth, R. (1968). Theory, method and American studies. In Robert Merideth (Ed.), From American studies (pp. 88-124). Columbus, OH: Charles E. Merill. 
IJHS, e-ISSN 2597-4718, p-ISSN 2597-470X, Vol. 1, No. 1, September 2017, pp. 37-46

Palmer, D. J. (1987) Historicism. In Roger Fowler (Ed.), A dictionary of modern critical terms (pp. 121-134). New York: Routledge \& Kegan Paul.

Pritzker, B. M. 1998). Native Americans: An encyclopedia of history, culture, and peoples. Santa Barbara, CA: ABC-CLIO Inc.

Selden et al. (2005). A reader's guide to contemporary literary theory $\left(5^{\text {th }} \mathrm{ed}\right.$.). Edinburg Gate: Pearson Education Limited.

Swartz, E. (1992). Multicultural education: From a compensatory to a scholarly foundation. In Carl A. Grant (Ed.), Research \& multicultural education: from the margins to the mainstream (pp. 31-42). Washington D.C.: The Falmer Press.

Tischauser, L.V. (2003). Reservation system of the united states. In Carole A. Barrett (Ed.), American Indian history (pp. 478-484). Pasadena, CA: Salem Press Inc. 